\title{
Terapi Kelompok Pendukung untuk Meningkatkan Resiliensi pada Ibu yang Memiliki Anak Talasemia
}

\author{
Yudi Kurniawan ${ }^{1}$, Fuad Nashori ${ }^{2}$, Indahria Sulistyarini ${ }^{3}$ \\ ${ }^{1}$ Prodi Psikologi, Fakultas Psikologi, Universitas Semarang, Indonesia \\ ${ }^{2,3}$ Prodi Psikologi, Fakultas Psikologi dan Ilmu Sosial Budaya, Universitas Islam Indonesia \\ e-mail: yudikurniawan@usm.ac.id
}

\begin{abstract}
This study aims to increase resilience in mothers who have thalassemia children with support group therapy. This study used a quasi-experimental design with a pretest-posttest control group design with follow-up. Respondents in this study were eight mothers of thalassemia patients who were divided into control groups and experimental groups. The scale used in this study is the Modified Connor-Davidson Resilience Scale. Data obtained in the study were analyzed using the Mann-Whitney nonparametric test to compare scores between groups given Support Groups Therapy and groups not given intervention. The results showed that there were differences in resilience scores between the control group and the experimental group after being given Support Group Therapy. This study concluded that Support Group Therapy was effective for increasing resilience in mothers who had children with thalassemia.
\end{abstract}

Keywords: resilience, support group therapy, thalassemia

\begin{abstract}
Abstrak
Penelitian ini bertujuan untuk meningkatkan resiliensi pada ibu yang memiliki anak talasemia dengan terapi kelompok pendukung. Penelitian ini menggunakan desain kuasi eksperimen dengan pretest-posttest control group design dengan tindak lanjut. Responden dalam penelitian ini adalah delapan ibu pasien talasemia yang dibagi menjadi kelompok kontrol dan kelompok eksperimen. Skala yang digunakan dalam penelitian ini adalah Modified Connor-Davidson Resilience Scale. Data yang diperoleh dalam penelitian dianalisis dengan menggunakan uji beda nonparametrik Mann-Whitney test untuk membandingkan skor antara kelompok yang diberikan Terapi Kelompok Pendukung dan kelompok yang tidak diberikan intervensi. Hasil penelitian menunjukkan bahwa ada perbedaan skor resiliensi antara kelompok kontrol dan kelompok eksperimen setelah diberikan Terapi Kelompok Pendukung. Penelitian ini menyimpulkan bahwa terapi kelompok pendukung efektif untuk meningkatkan resiliensi pada ibu yang memiliki anak talasemia.
\end{abstract}

Kata Kunci: resiliensi, terapi kelompok pendukung, talasemia

\section{Pendahuluan}

Talasemia merupakan kondisi genetik bawaan yang berhubungan dengan proses pembentukan hemoglobin (sel darah merah) sehat pada tubuh manusia. Orang yang mengalami talasemia akan kekurangan sel darah merah (hemoglobin) di dalam tubuhnya dan juga tidak memiliki sel darah merah sehat yang mencukupi. Sel darah merah pasien talasemia terbentuk tidak sempurna dan tidak mengandung cukup hemoglobin. Sel darah merah yang telah rusak tidak dapat memberikan oksigen yang dibutuhkan oleh tubuh pasien. Akibatnya, pasien talasemia tidak sanggup melakukan aktivitas fisik berat (seperti berolahraga, bekerja yang menuntut kekuatan fisik) dan kulit yang menghitam akibat penumpukan zat besi pada tubuh (Baer, 2014).

World Health Organization (WHO) mengungkapkan bahwa talasemia digolongkan sebagai salah satu penyakit keturunan dengan populasi terbanyak di 
dunia. Penyakit ini lazim ditemukan di kawasan Laut Tengah, Timur Tengah, Asia Selatan, dan Asia Tenggara (Ganie, 2005). Data WHO menampilkan bahwa ada sekitar $4.5 \%$ penduduk dunia $( \pm 315$ juta orang) membawa sifat genetik talasemia. Jumlah tersebut terus bertambah karena terdapat sekitar 350 ribu anak di seluruh dunia yang menderita talasemia setiap tahunnya (Ganie, 2005). Hingga saat ini, belum ditemukan obat yang mampu memulihkan kode genetik yang membawa sifat talasemia. Seseorang yang terdiagnosis talasemia harus menjalani transfusi darah setidaknya sebulan sekali sepanjang usia hidupnya (KOMPAS, 2013).

Dalam perspektif medis, pasien talasemia mengalami kekurangan produksi sel darah merah (hemoglobin) dalam tubuhnya. Akibatnya, darah tidak memiliki pasokan yang cukup untuk mengedarkan oksigen dan makanan ke seluruh tubuh. Oleh karena itu, pasien talasemia sering merasakan gejala awal seperti kepala pusing, badan lemas tiba-tiba, hingga tidak bisa tidur. Seorang pasien talasemia juga harus menahan diri untuk tidak mengonsumsi makanan yang mengandung kadar zat besi tinggi seperti daging merah dan hati. Mekanisme tubuh yang abnormal akan membuat zat besi menumpuk dan menyebabkan kerusakan pada organ dalam seperti jantung, hati, dan pankreas. Akibat dari penumpukan zat besi tersebut, rerata usia harapan hidup pasien talasemia sekitar 30an tahun. Pasien talasemia paling tua yang pernah bertahan hidup berusia hingga 41 tahun (Sukmawati, 2018).

Pasien talasemia sering mengeluh dengan proses transfusi darah yang harus mereka lakukan secara rutin setiap bulannya. Pasien talasemia juga tidak bisa bebas beraktivitas karena tubuh mereka mudah letih. Kebanyakan pasien talasemia tidak melanjutkan pendidikan atau terhenti pada jenjang sekolah menengah pertama. Perubahan bentuk fisik, seperti bentuk wajah dan perut (akibat pembesaran limpa), juga membatasi interaksi sosial pasien talasemia.

Berdasarkan wawancara yang dilakukan terhadap subjek RR yang memiliki anak talasemia berusia lima tahun pada 21 April 2015, peneliti mendapatkan data bahwa kemampuan fisik anak talasemia yang sangat terbatas dan harus rutin mendapatkan transfusi darah berdampak terhadap kondisi emosional ibu.

Pengalaman lain disampaikan oleh subjek RN yang memiliki anak talasemia berusia empat tahun. Berdasarkan hasil wawancara yang dilakukan pada tanggal 25 April 2015 terhadap subjek RN, diperoleh data bahwa subjek RN mengalami ketidakstabilan emosi akibat ditinggal pergi oleh suami dan anaknya yang didiagnosis talasemia. Subjek RN menangis setiap hari dan selalu merasa sedih saat melihat anaknya dirawat di rumah sakit untuk transfusi darah.

Proses adaptasi terhadap talasemia tidak hanya dialami oleh pasien, tetapi juga orang tua sebagai pendamping utama pasien (Kurniawan, 2011). Pada masa awal pasien mengalami talasemia, pengasuh umumnya mengalami tekanan psikologis karena harus ekstra mengawasi aktivitas pasien dan menemani pasien untuk transfusi darah. Selain faktor perubahan aktivitas, tidak jarang kehidupan pribadi orang tua ikut berubah. Ada orang tua yang bercerai karena pasangan tidak menerima kondisi anaknya. Ada pula orang tua yang tidak bercerai, namun istri ditinggalkan tanpa penghasilan oleh suaminya. Orang tua yang memiliki anak talasemia dituntut mampu bertahan dalam situasi sulit dan mampu fleksibel menghadapi tantangan dan perubahan. Mayoritas pasien talasemia mendapatkan diagnosis ketika masih berusia di bawah lima tahun, sehingga keberlangsungan hidup pasien ditentukan oleh kemampuan orang tua menghadapi tekanan psikologis (Kurniawan, 2011). Kemampuan orang tua untuk mengatasi kesukaran dan tetap mampu berfungsi optimal ketika menghadapi hambatan 
disebut dengan resiliensi (Kurniawan, 2011).

$$
\text { Resiliensi dicirikan sebagai }
$$

kemampuan individu untuk bangkit ketika menghadapi peristiwa tidak menyenangkan, dengan kestabilan emosi serta fungsi fisik maupun psikologis. Individu yang mengalami peristiwa tidak menyenangkan dan tidak memiliki ciri tersebut dikatakan sebagai individu yang tidak resilien (Scali, Gandubert, Ritchie, Soulier, Ancelin, \& Chaudieu, 2012). Konsep resiliensi dapat menjadi indikator terhadap kesehatan mental individu. Skor resiliensi yang rendah menjadi indikasi adanya masalah kesehatan mental pada individu (Scali dkk., 2012).

Terdapat tujuh keterampilan yang harus dimiliki individu agar mampu resilien. Pertama, keterampilan memahami pikiran-pikiran negatif yang menghambat kemajuan untuk diri sendiri. Kedua, menghindari jebakan pikiran berupa keinginan menyalahkan diri sendiri. Ketiga, mengenali ketakutan-ketakutan alam bawah sadar. Keempat, meningkatkan kemampuan untuk menyelesaikan masalah. Kelima, menempatkan masalah pada konteks yang tepat. Keenam, bersikap tenang dan fokus ketika menghadapi masalah. Ketujuh, menerapkan prinsip resiliensi dengan segera (Reivich \& Shatté, 2002).

Keterampilan-keterampilan tersebut dapat diperoleh salah satunya melalui dukungan sosial (Ablah \& Dong, 2014). Dukungan sosial ini dapat terwujud dalam berbagai bentuk, salah satunya dari sesama pengasuh yang memiliki anak talasemia. Pertemuan dan dukungan dari sesama pengasuh yang memiliki anak talasemia penting untuk menumbuhkan perasaan berdaya. Maria dan Indriati (2014) dalam penelitiannya menemukan bahwa pertemuan para orang tua ketika membawa anak mereka transfusi darah menjadi sumber energi positif tersendiri. Mereka sadar bahwa ada orang tua lain yang juga memiliki anak dengan talasemia. Fungsi dukungan tersebut dapat diwujudkan dalam bentuk terapeutik melalui Support Group Therapy (selanjutnya diterjemahkan sebagai Terapi Kelompok Pendukung).

Terapi Kelompok Pendukung berisi kelompok individu dengan masalah yang sama, saling memberikan dukungan sosial dan emosional (Smith, Cumming, \& XerosConstantinides, 2014). Inspirasi bisa datang dari proses pengamatan dan refleksi terhadap pengalaman peserta kelompok lain. Terapi Kelompok Pendukung sangat memungkinkan terjadinya proses pembelajaran sosial melalui imitasi dan modelling terhadap pengalaman anggota kelompok lain. Kelompok dapat berperan sebagai penampung emosi negatif anggotanya sekaligus tempat yang aman untuk berbagi pikiran dan pengalaman negatif. Proses pembelajaran dan dukungan yang diperoleh melalui anggota kelompok dapat menjadi sumber kekuatan individu untuk bangkit dan memperoleh energi baru (Smith dkk., 2014).

Berdasarkan pemaparan latar belakang masalah, peneliti tertarik untuk melihat bagaimana Terapi Kelompok Pendukung mampu meningkatkan resiliensi orang tua pasien talasemia. Terapi Kelompok Pendukung adalah intervensi yang memanfaatkan kekuatan empati tiap responden. Energi empati diubah menjadi bentuk dukungan dan penguatan terhadap kondisi diri sendiri dan anggota kelompok lainnya. Penjelasan sebelumnya tentang resiliensi menunjukkan bahwa dukungan dari orangorang yang mengalami masalah serupa merupakan salah satu faktor yang menentukan resiliensi (Mitchell dkk., 2007).

\section{Metode Penelitian}

Penelitian ini merupakan penelitian kuasi-eksperimen dengan model rancangan penelitian pretest-posttest control group design (Neuman, 2014). Desain ini bertujuan untuk melihat pengaruh suatu intervensi terhadap kelompok yang dikenakan perlakuan dibandingkan dengan kelompok yang tidak dikenakan perlakuan. 
Bentuk rancangan penelitian dapat dilihat pada gambar 1 .

\begin{tabular}{|cccc|}
\hline $\begin{array}{c}\text { Kelompok } \\
\text { Eksperimen } \\
\text { (KE) }\end{array}$ & Pra-tes & Perlakuan & Pasca-tes \\
$\begin{array}{c}\text { Kontrol } \\
\text { (KK) }\end{array}$ & Y1 & X & Y2 \\
\hline Gambar 1. Skema pretest-posttest control group \\
design
\end{tabular}

Keterangan:

Y1 : Pengukuran Pra-tes

Y2 : Pengukuran Pasca-tes

$\mathrm{X}$ : Perlakuan

-X : Tanpa perlakuan

Kriteria responden penelitian ini adalah: 1) Ibu yang memiliki minimal satu anak pasien talasemia; 2) Anak rutin menjalani transfusi darah; 3) Periode merawat pasien talasemia sekitar 3-6 tahun; dan 4) Memiliki skor resiliensi pada kisaran rendah hingga sedang (Kriteria ini diperlukan sebagai syarat proses screening and matching kelompok eksperimen dan kontrol)

Responden dalam penelitian ini ditentukan dengan non-random sampling, yang mana responden bukan merupakan representasi dari populasi umum karena kategori kasus klinis yang unik, sulit mengambil sampel dalam jumlah besar, dan membutuhkan investigasi mendalam. Sesuai dengan konteks penelitian, responden yang diambil adalah ibu yang memiliki anak talasemia. Penentuan anggota kelompok kontrol dan eksperimen menggunakan teknik screening dan matching. Prosedur ini dilakukan dengan menyeleksi responden penelitian yang memiliki tingkat resiliensi pada kategori sedang dan rendah. Responden penelitian adalah ibu pasien talasemia yang telah diukur tingkat resiliensinya dan berada pada kategori sedang dan rendah.
Penelitian ini dilakukan pada dua kelompok, yaitu kelompok eksperimen dan kelompok kontrol. Kelompok eksperimen mendapatkan perlakuan berupa Terapi Kelompok Pendukung. Materi dan prosedur Terapi Kelompok Pendukung peneliti susun dalam bentuk modul. Kelompok kontrol diperlakukan dalam daftar tunggu yang akan tetap diberikan perlakuan setelah seluruh proses intervensi berakhir.

Pra-tes dilakukan sebelum intervensi dilaksanakan. Tingkat resiliensi anggota kelompok diukur dengan menggunakan Modified Connor-Davidson Resilience Scale. Responden yang memiliki skor resiliensi rendah hingga sedang diambil sebagai anggota kelompok eksperimen. Tindak lanjut akan dilakukan untuk melihat pengaruh terapi yang telah dilakukan dengan melakukan diskusi kelompok terarah.

Variabel resiliensi diukur dengan menggunakan skala resiliensi CD-RISC 27 item. Skala tersebut menggunakan lima alternatif pilihan respon, yaitu selalu, sering, kadang-kadang, jarang, dan tidak pernah. Rentang skor yang diberikan untuk masing-masing item bergerak dari 1-5. Skor 1 untuk pilihan tidak pernah, skor 2 untuk pilihan jarang, skor 3 untuk pilihan kadang-kadang, skor 4 untuk pilihan sering, dan skor 5 untuk pilihan selalu. Skor terendah yang mungkin diperoleh responden adalah 27 dan skor tertinggi yang mungkin diperoleh responden adalah 135. Semakin tinggi skor yang diperoleh responden, maka semakin tinggi pula kemampuan resiliensinya. Selanjutnya peneliti akan melakukan kategorisasi skor menjadi tiga bagian, yaitu rendah, sedang, dan tinggi (Azwar, 2014). 


\section{Hasil Penelitian dan Pembahasan}

\section{Hasil Penelitian}

Responden penelitian adalah ibu yang memiliki anak dengan diagnosis talasemia. Responden dalam penelitian ini berjumlah sebelas orang yang kemudian dibagi ke dalam dua kelompok, yaitu enam responden sebagai kelompok eksperimen dan lima responden sebagai kelompok kontrol. Pembagian responden pada kelompok eksperimen dan kelompok kontrol dikakukan dengan metode matching group. Pada terapi pertemuan kedua, tiga orang anggota kelompok eksperimen tidak dapat meneruskan proses terapi, sehingga kelompok eksperimen tersisa tiga responden.

Jumlah responden penelitian pada kelompok eksperimen sebanyak enam orang. Responden yang masuk ke dalam kelompok eksperimen merupakan peserta terapi yang dilakukan selama tiga kali pertemuan. Peneliti melakukan pengukuran skala sebanyak tiga kali, yaitu sebelum intervensi dilakukan (pra-tes), setelah intervensi diberikan (pasca-tes) dan dua minggu setelah intervensi diberikan (tindak lanjut). Adapun deskripsi data penelitian dapat dilihat pada gambar 2 dan gambar 3 .

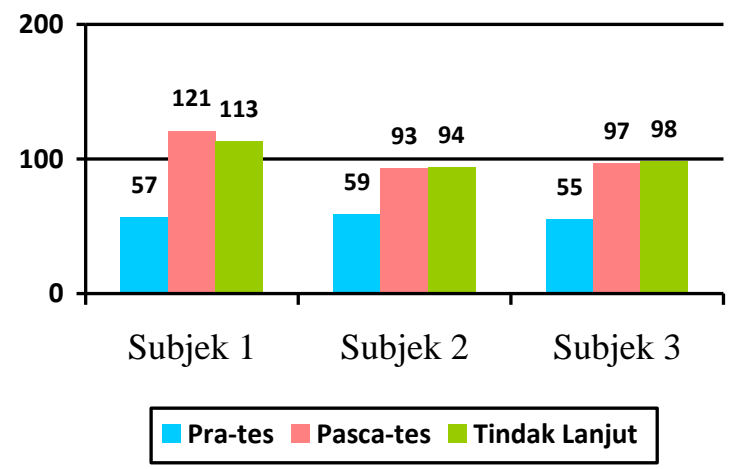

Gambar 2. Data kelompok eksperimen

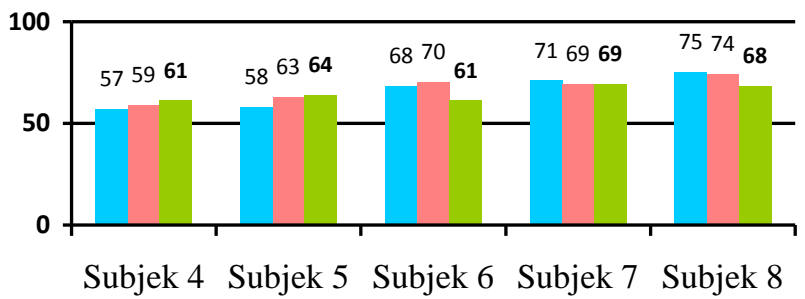

Pra-tes Pasca-tes Tindak Lanjut

Gambar 3. Data kelompok kontrol

Skor pasca-tes pada gambar 2 dan 3 menunjukkan bahwa seluruh responden kelompok eksperimen mengalami peningkatan skor resiliensi setelah mendapatkan intervensi Terapi Kelompok Pendukung. Pada saat tindak lanjut, satu responden mengalami penurunan skor resiliensi dan dua orang responden mengalami kenaikan skor resiliensi. Pada kelompok kontrol, terlihat pula adanya kenaikan maupun penurunan skor resiliensi baik pada pasca-tes maupun tindak lanjut. Namun demikian kenaikan atau penurunan skor yang bernilai sangat kecil tersebut dapat dianggap tidak signifikan.

Tabel 1

Deskripsi Data Statistik

\begin{tabular}{lccccccccc}
\hline & \multicolumn{4}{c}{ Eksperimen } & \multicolumn{4}{c}{ Kontrol } \\
\cline { 2 - 9 } & \multicolumn{3}{c}{ Min } & Max & Re- & \multicolumn{5}{c}{$\begin{array}{c}\text { Re- } \\
\text { Rata }\end{array}$} & SD & Min & Max & rata & SD \\
\hline Pra-tes & 55 & 59 & 57 & 2 & 57 & 75 & 65.8 & 7.9 \\
Pasca-tes & 93 & 121 & 103.7 & 15.1 & 61 & 72 & 65.4 & 4.9 \\
$\begin{array}{l}\text { Tindak } \\
\text { Lanjut }\end{array}$ & 94 & 113 & 101.7 & 10 & 65 & 73 & 67.8 & 3.1 \\
\hline
\end{tabular}

Berdasarkan tabel 1, rerata pra-tes pada kelompok eksperimen sebesar 57 dan kelompok kontrol sebesar 65.8. Data tersebut memperlihatkan bahwa rerata skor pra-tes resiliensi pada kelompok kontrol lebih tinggi dibandingkan dengan rerata skor pra-tes pada kelompok eksperimen. Saat pasca-tes, rerata kelompok eksperimen naik menjadi 103.7, lebih tinggi dibandingkan dengan rerata kelompok kontrol senilai 65.4. Kondisi ini juga muncul saat tindak lanjut. Rerata skor pada 
kelompok eksperimen sebesar 101.7 lebih tinggi dibandingkan dengan rerata skor pada kelompok kontrol yaitu sebesar 67.8.

Tabel 2

Uji Beda dengan Menggunakan Skor Resiliensi

\begin{tabular}{lcc}
\hline & $\mathrm{Z}$ & $P$ \\
\hline Pra-tes & -1.500 & .134 \\
Pasca-tes & -2.249 & .024 \\
Tindak Lanjut & -2.236 & .025 \\
\hline
\end{tabular}

Berdasarkan tabel 2, skor pra-tes memperlihatkan bahwa tidak ada perbedaan resiliensi antara kelompok kontrol dan kelompok eksperimen dengan signifikansi $\mathrm{p}=.134 \quad(\mathrm{p}>.05)$. Selanjutnya, terdapat perbedaan skor resiliensi antara responden pada kelompok eskperimen dan responden pada kelompok kontrol pasca intervensi dan saat tindak lanjut. Skor dikatakan ada perbedaan jika nilai $\mathrm{p}<.05$. Hal ini ditunjukkan oleh skor resiliensi pasca-tes dengan $\mathrm{p}=.024 \quad(\mathrm{p}<.05)$, yang berarti ada perbedaan antara skor resiliensi kelompok kontrol dan kelompok eksperimen. Perbedaan juga terjadi pada skor resiliensi tindak lanjut antara kelompok kontrol dan kelompok eksperimen dengan $\mathrm{p}=.025$ $(\mathrm{p}<.05)$.

\section{Pembahasan}

Penelitian ini menguatkan hasil penelitian sebelumnya yang dilakukan oleh (Smith dkk., 2010). Hasil penelitian tersebut menunjukkan bahwa Terapi Kelompok Pendukung yang dilakukan terhadap ibu dengan bayi berisiko tinggi berhasil meningkatkan hubungan positif antara ibu dan anak. Terapi Kelompok Pendukung dapat mengurangi perasaan negatif yang dirasakan oleh orang tua/ caregiver yang merawat pasien dengan penyakit kronis, masalah kejiwaan, atau lansia (Paleg \& Jongsma Jr, 2015). Peneliti menemukan bahwa Terapi Kelompok Pendukung yang diterapkan terhadap ibu pasien talasemia dapat menjadi wadah untuk menyalurkan emosi negatif, saling belajar dari pengalaman responden lain, dan membuat diri mereka berharga dengan membantu responden lain.

Terapi Kelompok Pendukung merupakan bentuk intervensi bagi ibu pasien talasemia. Dalam prosesnya, terdapat sesi saling berbagi informasi, diskusi masalah, pengungkapan pikiran dan perasaan, serta berbagi pengalaman dan pembelajaran pemecahan masalah dari peserta dan fasilitator. Sebelum terapi dimulai, fasilitator mendiskusikan aturan kelompok agar proses selanjutnya disepakati oleh seluruh peserta (Brabender, Smolar, \& Fallon, 2014).

Aturan di dalam kelompok perlu disepakati untuk membangun sikap saling percaya antar anggota kelompok sehingga mereka saling terbuka terhadap masalahnya. Pembentukan aturan di dalam kelompok menjadi hal yang sangat penting karena aturan kelompok dapat membantu seseorang lebih terbuka dan percaya terhadap kelompok (Prawitasari, 2011). Peserta dapat memahami aturan kelompok sehingga dalam proses intervensi antar anggota kelompok dapat saling menjaga rahasia dan dapat merasa nyaman untuk menceritakan pengalaman hidup mereka. Lazimnya, sebelum pertemuan pertama diakhiri, fasilitator perlu menggali pikiran ataupun perasaan yang muncul pada diri peserta terapi (Prawitasari, 2011).

Terapi Kelompok Pendukung memiliki beberapa unsur yang mendukung keberhasilan intervensi, diantaranya yaitu kelompok dapat memberikan kesempatan pada anggota untuk saling memberi dan menerima umpan balik, dengan cara ini kelompok akan belajar mengenai informasi dan perilaku yang baru. Selain itu juga Terapi Kelompok Pendukung dapat menjadi sarana untuk berbagi pengalaman serta menuangkan ide dan perasaan anggota kelompok sehingga anggota kelompok yang lain dapat memberikan pendapat yang akan mengubah sikap dan perilaku anggota kelompok lainnya (Brabender dkk., 2014).

Dukungan dari sesama anggota menjadi unsur yang sangat penting dalam 
keberhasilan Terapi Kelompok Pendukung. Melalui dukungan antar sesama, anggota kelompok akan merasa diterima dan mendapatkan perhatian dari orang lain sekaligus belajar untuk melatih keterampilan sosial. Responden intervensi juga dapat belajar untuk membuat suasana positif bagi orang lain. Langkah seperti ini akan meningkatkan hubungan interpersonal yang efektif. Hubungan yang efektif menjadikan antar anggota kelompok memiliki kepercayaan dan kenyamanan untuk berbagi informasi dan pengalaman serta memberikan umpan balik kepada anggota lainnya. Peneliti mengamati bahwa situasi saling dukung juga terjadi selama proses intervensi (Taylor, Wells, Howell, \& Raphael, 2016)

Penelitian kualitatif mengenai pasien talasemia juga menyebutkan bahwa penerimaan dan dukungan orang tua terhadap pasien adalah faktor kunci penentu resiliensi (Kurniawan, 2011). Faktor ini menjadi dasar bagi anak untuk membentuk strategi adaptasi di masa perkembangan fisik dan psikologis berikutnya. Jika orang tua pasien talasemia dapat menerima dan memberikan dukungan psikologis yang tepat terhadap anak, maka anak akan mampu membantu dirinya sendiri dengan strategi adaptasi yang tepat. Peningkatan fungsi keluarga, terutama peran orang tua, akan membantu mengurangi stres pada anak yang mengalami masalah psikologis dan mempromosikan perilaku resiliensi kepada seluruh anggota keluarga (Lester, Stein, Saltzman, Woodward, MacDermid, Milburn, \& Beardslee, 2014).

Faktor penentu resiliensi (resilient deteminant) menjelaskan hal-hal yang membantu individu untuk bangkit dari kondisi sulit. Dalam konfirmasi yang penulis lakukan, Bogar menjelaskan bahwa faktor penentu resiliensi serupa dengan istilah faktor protektif (Bogar \& Hulse-Killacky, 2016). Perbedaan kedua hal tersebut terletak pada penelitian yang mendahuluinya. Istilah faktor protektif muncul dari penelitian kuantitatif yang membuat faktor tersebut dapat digunakan secara universal. Sementara faktor penentu resiliensi berasal dari penelitian kualitatif yang sifatnya lebih spesifik dan kasuistik. Agar tidak menimbulkan kebingungan dengan istilah faktor protektif yang peneliti dapatkan dari penelitian terdahulu, maka istilah faktor penentu resiliensi dan faktor protektif digunakan secara bergantian untuk pembahasan (Bogar \& Hulse-Killacky, 2016).

Sikap mengasihi diri sendiri (selfcompassion) menjadi salah satu faktor yang menguatkan kemunculan resiliensi pada diri individu (Hayter \& Dorstyn, 2014). Artinya, individu mampu menjadi resilien jika sebelumnya mampu menerima dirinya terlebih dahulu, dengan segala kekurangannya. Ketiga responden dalam penelitian ini termasuk ke dalam kategori tersebut. Ketika baru mengetahui bahwa anaknya terdiagnosis talasemia, mereka cenderung menyalahkan diri sendiri dan situasi di sekitarnya. Proses terapi dan saling berbagi kemudian mengajarkan mereka untuk menyayangi diri sendiri dan memberikan ruang ekspresi emosi pada diri sendiri. Sikap mengasihi diri sendiri sangat terkait dengan bagaimana hubungan antara responden dan anak mereka yang mengalami talasemia. Resiliensi dapat berpengaruh terhadap banyak hal, seperti peningkatan kualitas kesehatan mental dan atau mengurangi gejala penyakit fisik tertentu. Hasil yang diperoleh pun berbedabeda di tiap wilayah, sehingga faktor kebudayaan dan agama menjadi salah satu penentu kemampuan resiliensi individu (Dale, Cohen, Kelso, Cruise, Weber, Watson, \& Brody, 2014)

Berdasarkan hasil statistik, aspek yang mengalami peningkatan dan perubahan signifikan adalah pengaruh spiritual. Spiritual tidak hanya dikaitkan dengan perilaku beribadah, tetapi juga terhadap perilaku responden yang memerlihatkan bahwa mereka yakin dengan keterlibatan Tuhan dalam situasi dirinya saat ini dan mengenai hubungan sebab akibat terkait 
apapun perbuatan yang telah dilakukan oleh responden (Adz-Dzakiey, 2007). Seluruh responden menyatakan bahwa mereka yakin bahwa kondisi anak yang mengalami talasemia adalah pemberian Tuhan yang ditakdirkan dengan cara berbeda dibandingkan dengan orang lain. Perspektif tersebut mampu membuat responden bersyukur dan dapat menjalani kehidupan dengan menumbuhkan harapan baru. Resiliensi merupakan hasil dari proses penyesuaian diri terhadap kondisi kehidupan yang tidak menguntungkan. Proses tersebut dapat berbentuk adaptasi pola pikir yang memilih paradigma positif untuk melihat dan menyelesaikan masalah yang sedang dihadapi oleh individu tersebut (Hayter \& Dorstyn, 2014).

Kondisi yang dialami responden selaras dengan pernyataan Hefti (2009) tentang integrasi aspek spiritual dalam proses terapi. Aspek spiritual seringkali menjadi cara bagi individu yang mengalami hambatan psikologis untuk menyelesaikan masalah mereka. Hefti (2009) mengindikasikan bahwa 70-80 persen individu memperoleh keuntungan psikologis dari proses spiritual yang mereka terapkan. Pada kasus dalam penelitian ini, seluruh responden adalah pemeluk agama Islam. Sebelum terapi, responden cenderung skeptis terhadap kebaikan dan bantuan dari Tuhan. Namun proses terapi membantu mereka untuk mengubah keyakinan tersebut. Keyakinan terhadap Tuhan sangat membantu responden dalam membangun harapan, tujuan, dan menciptakan makna terhadap seluruh peristiwa yang telah terjadi.

Faktor dukungan menjadi sangat penting karena setiap anggota kelompok mengawali proses terapi dengan suasana emosi yang tidak nyaman karena masalah yang mereka alami. Dukungan yang diterima dari anggota kelompok lainnya dapat memantik inspirasi, harapan, penerimaan terhadap diri sendiri, sikap saling menolong, dan perasaan kebersamaan sebagai satu kelompok.
Dukungan dan sikap menerima satu sama lain dari anggota kelompok dapat meningkatkan harapan terhadap semua responden untuk menciptakan dan mencapai tujuan di masa depan. Pada hakikatnya, resiliensi adalah proses menciptakan keyakinan pada individu bahwa harapan dan tujuan itu selalu ada, meskipun hidup selalu didera oleh tantangan.

\section{Simpulan}

Hasil penelitian menunjukkan bahwa Terapi Kelompok Pendukung efektif untuk meningkatkan nilai skor resiliensi pada ibu pasien talasemia. Kelompok yang mendapatkan intervensi memiliki skor resiliensi yang lebih tinggi dibandingkan dengan kelompok yang tidak mendapatkan terapi kelompok pendukung.

\section{Daftar Pustaka}

Ablah, E., \& Dong, F. (2014). [Erratum] a modified cd-risc: Including previously unaccounted for resilience variables.

Adz-Dzakiey, H. B. (2007). Psikologi kenabian: Prophetic psychology: Menghidupkan potensi dan keperibadian kenabian dalam diri. Pustaka Al-Furqan.

Azwar, S. (2014). Metode penelitian. Pustaka Pelajar: Yogyakarta.

Baer, K. (2014). A guide to living with thalassemia. London: Cooley Anemia Foundation.

Bogar, C. B., \& Hulse-Killacky, D. (2016). Resiliency determinants and resiliency processes among female adult survivors of childhood sexual abuse. Journal of Counseling \& Development, 84(3), 318-327.

Brabender, V. M., Smolar, A. I., \& Fallon, A. E. (2014). Essentials of group therapy (Vol. 29). John Wiley \& Sons.

Dale, S. K., Cohen, M. H., Kelso, G. A., Cruise, R. C., Weber, K. M., Watson, C., \& Brody, L. R. (2014). Resilience 
among women with HIV: Impact of silencing the self and socioeconomic factors. Sex Roles, 70(5-6), 221-231.

Ganie, R. A. (2005). Thalassemia: Permasalahan dan penanganannya. (Pidato pengukuhan jabatan guru besar tetap). Universitas Sumatera Utara Medan, Fakultas Kedokteran.

Hayter, M., \& Dorstyn, D. (2014). Resilience, self-esteem and selfcompassion in adults with spina bifida. Spinal cord, 52(2), 167-71.

Hefti, R. (2009). Integrating spiritual issues into therapy. Dalam P. Huguelet \& H. Koenig (Authors), Religion and spirituality in psychiatry (hal. 244267). Cambridge: Cambridge University Press. doi:10.1017/CBO9780511576843.017

KOMPAS. (2013). Adakah jejak thalassemia pada anda?. Kompas.com. Diakses pada 14 Februari 2019, dari https://nasional.kompas.com/read/2013 /05/08/08123451/adakah.jejak.thalasse mia.pada.anda

Kurniawan, Y. (2011). Pembentukan resiliensi (resilient formation) pada penderita thalassemia. Khazanah: Jurnal Mahasiswa, 4(1), 9-24.

Lester, P., Stein, J. A., Saltzman, W., Woodward, K., MacDermid, S. W., Milburn, N., \& Beardslee, W. (2014). Psychological health of military children: Longitudinal evaluation of a family-centered prevention program to enhance family resilience. Military Medicine, 178(8), 838-845.

Maria, A., \& Indriati, G. (2014). Pengalaman ibu dalam merawat anak dengan talasemia. Jurnal Online Mahasiswa Program Studi Ilmu Keperawatan Universitas Riau, 1(1), 1-7.

Mitchell, A. M., Wesner, S., Garand, L., Gale, D. D., Havill, A., \& Brownson, L. (2007). A support group intervention for children bereaved by parental suicide. Journal of Child and
Adolescent Psychiatric Nursing, 20(1), 3-13.

Neuman, W. L. (2014). Social research methods: Qualitative and quantitative approaches. Pearson education.

Paleg, K., \& Jongsma Jr, A. E. (2015). The group therapy treatment planner (Vol. 191). John Wiley \& Sons.

Prawitasari, J. E. (2011). Psikologi klinis pengantar terapan mikro dan makro. Jakarta: Erlangga.

Reivich, K., \& Shatté, A. (2002). The resilience factor: 7 essential skills for overcoming life's inevitable obstacles. Broadway Books.

Scali, J., Gandubert, C., Ritchie, K., Soulier, M., Ancelin, M. L., \& Chaudieu, I. (2012). Measuring resilience in adult women using the 10items Connor-Davidson Resilience Scale (CD-RISC). Role of trauma exposure and anxiety disorders. PloS one, $\quad 7(6)$, https://doi.org/10.1371/journal.pone.00 $\underline{39879}$

Smith, J. C., Cumming, A., \& XerosConstantinides, S. (2014). A decade of parent and infant relationship support group therapy programs. International Journal of Group Psychotherapy, 60(1), 59-89.

Sukmawati. (2018, September 20). Mengenali Penyakit Thalassemia. Diakses pada 14 Februari 2019, dari Tempo website: https://gaya.tempo.co/read/279105/me ngenali-penyakit-thalassemia

Taylor, M., Wells, G., Howell, G., \& Raphael, B. (2016). The role of social media as psychological first aid as a support to community resilience building. Australian Journal of Emergency Management, 27(1), 20-6. 
Psympathic, Jurnal Ilmiah Psikologi Juni 2019, Vol. 6, No. 1, Hal. : 31-40 